\title{
Non-symbiotic Seed Germination and In vitro Plant Development of Pholidota articulata
}

\author{
R. Devendra Prasad, Shreeti Pradhan, Mukti Ram Paudel and Bijaya Pant* \\ Central Department of Botany, Tribhuvan University, Kirtipur, Kathmandu, Nepal \\ *Corresponding Author's Email: b.pant@cdbtu.edu.np \\ *Orcid ID: https://orcid.org/0000-0001-5614-6031
}

Received on: 18 September 2020, Revised on: 28 December 2020, Accepted on: 14 January 2021

\begin{abstract}
Pholidota articulata is an epiphytic orchid mostly used in ornamental cut/pot flower and in traditional medicine. As it has high ornamental and medicinal values, its population from natural habitats is decreasing, therefore, it is listed in the Appendix-II of Convention on International Trade in Endangered Species (CITES). The objective of the present study is to obtain the in vitro plants of $P$. articulata from seed culture to conserve its germplasm. The in vitro seed germination was carried out in different strengths of Murashige and Skoog (MS) and Knudson $\mathrm{C}(\mathrm{KnC})$ medium supplemented with various plant hormones. On the half-strength of MS medium, seeds were started to germinate after 4 weeks of primary culture and they were developed into protocorms with first leaf primordium earlier than on the other medium. Therefore, in vitro developed protocorms were sub-cultured on the half-strength of MS medium supplemented with different concentrations of 6-benzylaminopurine (BAP), gibberellic acid $\left(\mathrm{GA}_{3}\right)$ and $\alpha$-naphtalene acetic acid (NAA). They were successfully developed into shoots on the $1.5 \mathrm{mg} / 1 \mathrm{BAP}$ supplemented half-strength of MS medium. Later, they were inoculated on the half-strength of MS medium supplemented with different concentration of $\alpha$-napthalene acetic acid (NAA), indole-3-acetic acid (IAA) and indole-3-butyric acid (IBA) for the root formation, where IBA supplemented medium was found effective for the development of roots. Thus, this study provides a reliable protocol for non-symbiotic seed germination and plant production, and reveals that seed-derived protocorms are good explants for the in vitro mass propagation for conservation and sustainable utilization in horticulture.
\end{abstract}

Keywords: Nutrient medium; Pholidota articulata, Propagation, Protocorms, Seed germination

\section{Introduction:}

The genus Pholidota, represented by 46 species in the world and by 5 species in Nepal, are distributed from tropics and subtropics to South-West Pacific (Chase et al., 2015; Rajbhandari, 2014). Pholidota articulata Lindl. is a fragrant, medium-sized, epiphytic or lithophyte found in Nepal, India, Tibet, China, Burma, Thailand, Laos, Cambodia, Vietnam, Borneo, Java, Sulawesi, and Sumatra (Rajbhandari, 2014). $P$. ariculata, commonly known as Articulated Pholidota, is grown in semi-deciduous and evergreen montane forests and highland primary cloud forests at an altitude of 300 to $2000 \mathrm{~m}$ (Pant et al., 2016). It has the ability of the arising of new pseudobulb from the apex of last year's mature pseudobulb and has ovate to linear-lanceolate leaves with prominent veins. It blooms on a slender, drooping, 6" to 11" long, fructifies inflorescence with broad, brownish floral bracts that drop as the many scented flowers with smelling of musk open in the spring and summer (Pant et al., 2016). The whole plant is used in traditional medicine such as bone fractures, age sustaining tonic and restorative, and in the preparation of 'Chyawanprash'. Its root powder is also used to treat cancer, ulcer and skin eruptions (Jalal et al., 2009; Sharma et al., 2017). This orchid is also

Copyright (C) 2021 Nepal Horticulture Society. This article is licensed under Creative Commons Attribution 4.0 International License. This permits unrestricted use, distribution and reproduction in any medium provided the original work is properly cited. All the authors declares that there is no any conflict of interest. 
equally important for aesthetic value as an ornamental purpose in the form of pot flower as well as a cut flower. As one of the important ingredient of Chyawanprash and having ornamental value as a cut/pot flower, plants of this species are declining from the nature due to over-collection to meet the demand (Subedi et al., 2013). Sexual reproduction of orchids in nature is being very slow as only $2-5 \%$ of their seeds can germinate after symbiosis with a special mycorrhizal fungus (Pant et al., 2017). So, plant tissue culture technique is one of the alternative ways to propagate the plants through seeds without fungal association those cannot be reproduced sexually in nature easily (Pant, 2013). In vitro propagation protocol by plant tissue culture has not been developed yet in this orchid. Thus, in this research, we have reported its in vitro non-symbiotic seeds germination and the plant production from seed-derived protocorms. In vitro propagation of this orchid could be an alternative to fulfill its demand on horticulture and traditional medicine as well as for its conservation.

\section{Materials and Methods}

\section{Plant material and its sterilization}

Healthy green capsules (16 weeks old) were collected from mother plant Pholidota articulata (Figure $1 \mathrm{~A}$ and B) grown in the botanical garden of Central Department of Botany, Tribhuvan University, Kathmandu (at an altitude of $1300 \mathrm{~m}$ asl). Seeds of a capsule were used as initial explant. The capsule was cleaned thoroughly under tap water followed by washing with few drops of Tween-20 (liquid detergent) for 30 minutes and finally rinsed with distilled water. It was surface sterilized with $70 \%$ ethanol for 5 minutes followed by an aqueous solution of $1 \%$ sodium hypochlorite for 10 minutes and finally rinsed with sterile distilled water for five times.

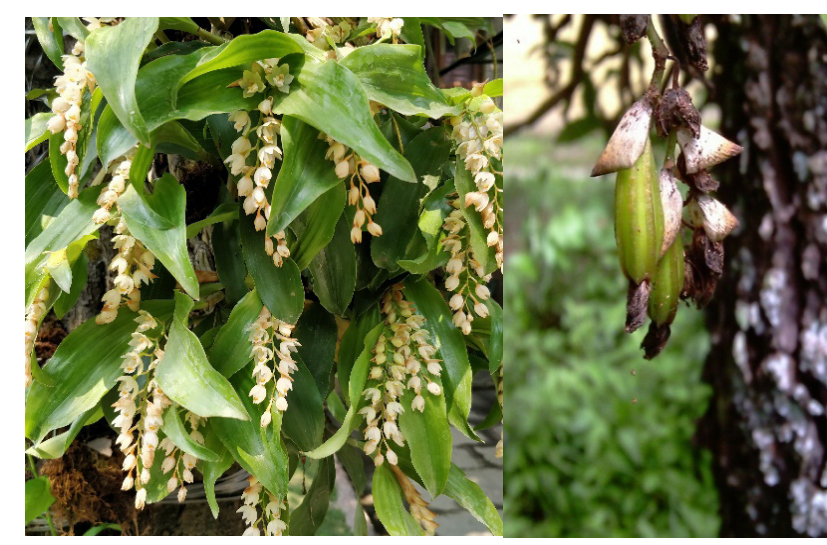

Figure 1:Pholidota articulata (A), and its capsules (B).

\section{Nutrient medium for culture}

Murashige and Skoog (MS) and Knudson C (KnC) medium were used as the basal nutrient medium. Full, half and quarter strength of them were used individually. Different concentration of 6-benzylaminopurine (BAP), gibberellic acid $\left(\mathrm{GA}_{3}\right), \alpha$-naphtalene acetic acid (NAA), indole-3-acetic acid (IAA) and indole-3butyric acid (IBA) have been added in both the nutrient medium for seeds germination, shoots elongation and multiplication, and roots formation. In the entire medium, $3 \%(\mathrm{w} / \mathrm{v})$ sucrose was added as carbon source and $0.8 \%(\mathrm{w} / \mathrm{v})$ agar was added as a gelling agent. The $\mathrm{pH}$ of all the medium was adjusted to 5.8 with $0.1 \mathrm{~N}$ $\mathrm{NaOH}$ or $\mathrm{HCl}$ before autoclaving. All the medium were autoclaved at $121^{\circ} \mathrm{C}$ and 15 psi for 20 minutes.

\section{Inoculation and germination of seeds}

The surface-sterilized capsule was cut longitudinally apart on sterilized petridish and seeds were spread thinly over the surface of solidified nutrient medium. Full-, half- and quarter-strength of MS and $\mathrm{KnC}$ medium, and full-strength of $\mathrm{MS}$ and $\mathrm{KnC}$ medium supplemented with $0.5 \mathrm{mg} / 1 \mathrm{BAP}$ and $0.5 \mathrm{mg} / \mathrm{l} \mathrm{NAA}$ was used for nonsymbiotic seeds germination.

\section{Elongation and multiplication of shoots}

Protocorms with first initiated leaf developed from the germinating seeds were used for shoots multiplication. Half-strength of MS medium with different concentration of $\mathrm{GA}_{3}(0.5,1.0,1.5$ and $2.0 \mathrm{mg} / \mathrm{l})$ with or without $0.5 \mathrm{mg} / \mathrm{L} \mathrm{NAA}$, and different concentration of BAP $(0.5,1.0,1.5$ and $2.0 \mathrm{mg} / \mathrm{l})$ were used for the elongation and multiplication of shoots from the seed derived-protocorms.

\section{Roots formation on shoots}

In vitro developed shoots were transferred on the halfstrength of MS medium supplemented with different concentrations $(0.5$ and $1.0 \mathrm{mg} / \mathrm{l})$ each of NAA, IAA and IBA for the development of roots on the shoots.

\section{Culture condition}

All the cultures were kept in the culture room at $25 \pm 2$ ${ }^{\circ} \mathrm{C}$. The culture room has facilitated with 16 hours of light period by fluorescent white light. 


\section{Statistical data analysis}

All the data were presented as a mean \pm standard error of the mean in each treatment. Univariate analysis was done using SPSS.

\section{Results}

\section{Germination of seeds on different nutrient medium}

Seeds were inoculated on the full-, half-, and quarterstrength of $\mathrm{MS}$ and $\mathrm{KnC}$ medium, and full-strength of MS and $\mathrm{KnC}$ medium supplemented with $0.5 \mathrm{mg} / \mathrm{l}$ BAP and $0.5 \mathrm{mg} / \mathrm{l} \mathrm{NAA}$. Their stages of development into protocorms and shoots have shown in Figure 2. Sign of seeds germination is by turning them into light yellowish-green on $4^{\text {th }}$ week, they became swollen and elongated spherules in $6^{\text {th }}$ week on all the strengths of MS medium and in $5^{\text {th }}$ week on all strengths of $\mathrm{KnC}$ medium. Protocorms formation was observed in $10^{\text {th }}$ week of seeds culture on full- and half-strength of MS medium (Figure $3 \mathrm{~A}$ and B). They were proliferated into shoots on half-strength of MS medium in $22^{\text {nd }}$ week. Similarly, protocorms were observed in $8^{\text {th }}$ week of seeds culture on full- and half-strength of $\mathrm{KnC}$ medium. They were globular, light yellowish-green and hairy. They were developed into shoots on halfand quarter-strength of $\mathrm{KnC}$ medium in $19^{\text {th }}$ week of primary culture (Figure $3 \mathrm{C}$ and D). The green, globular hairy protocorms changed into pale yellow over time on these medium. No shoot proliferation or further growth of protocorms was observed in all the concentrations and combinations of the $\mathrm{KnC}$ medium.

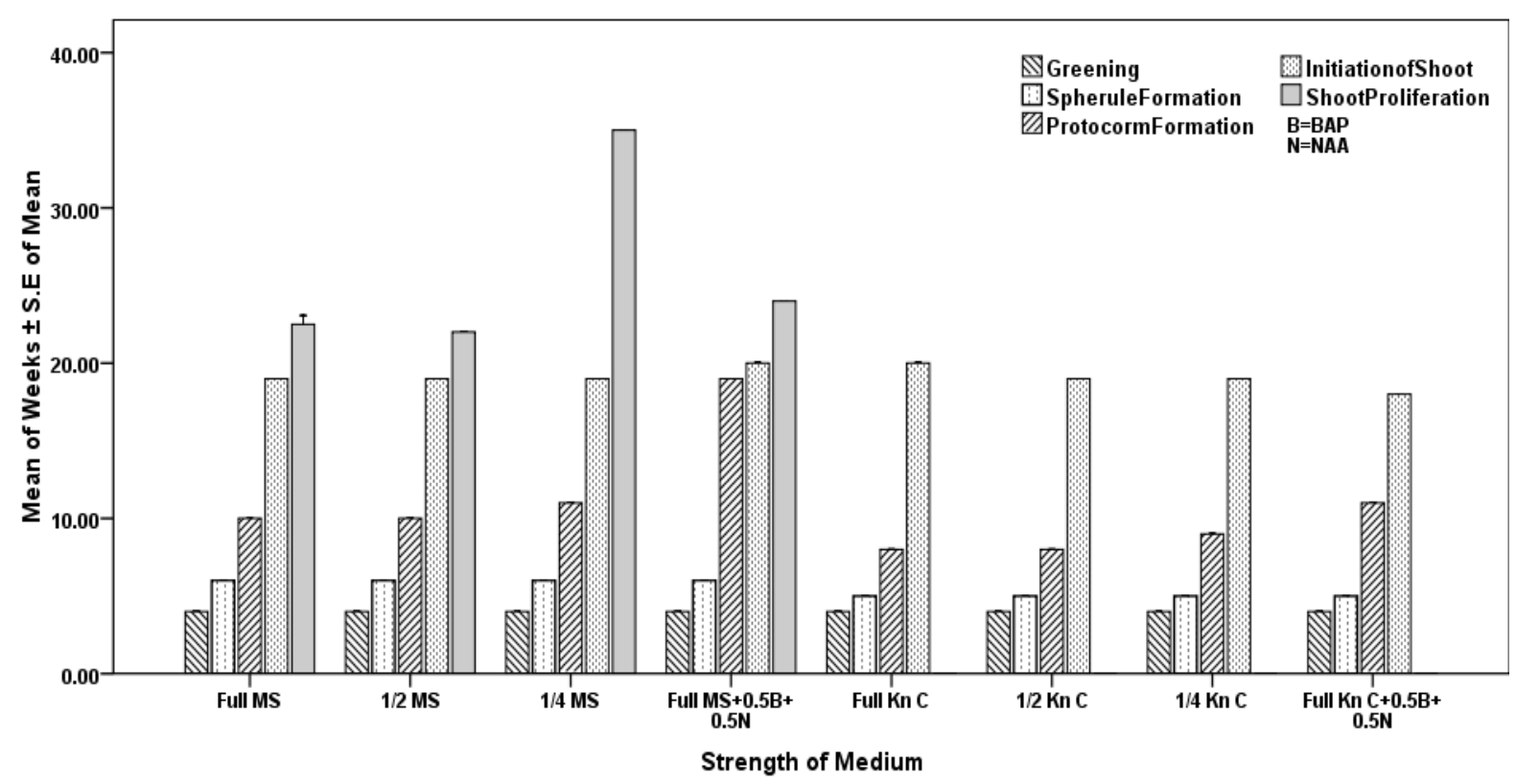

Figure 2: Germination of seeds on the different strength of MS and $\mathrm{KnC}$ medium with plant hormones.

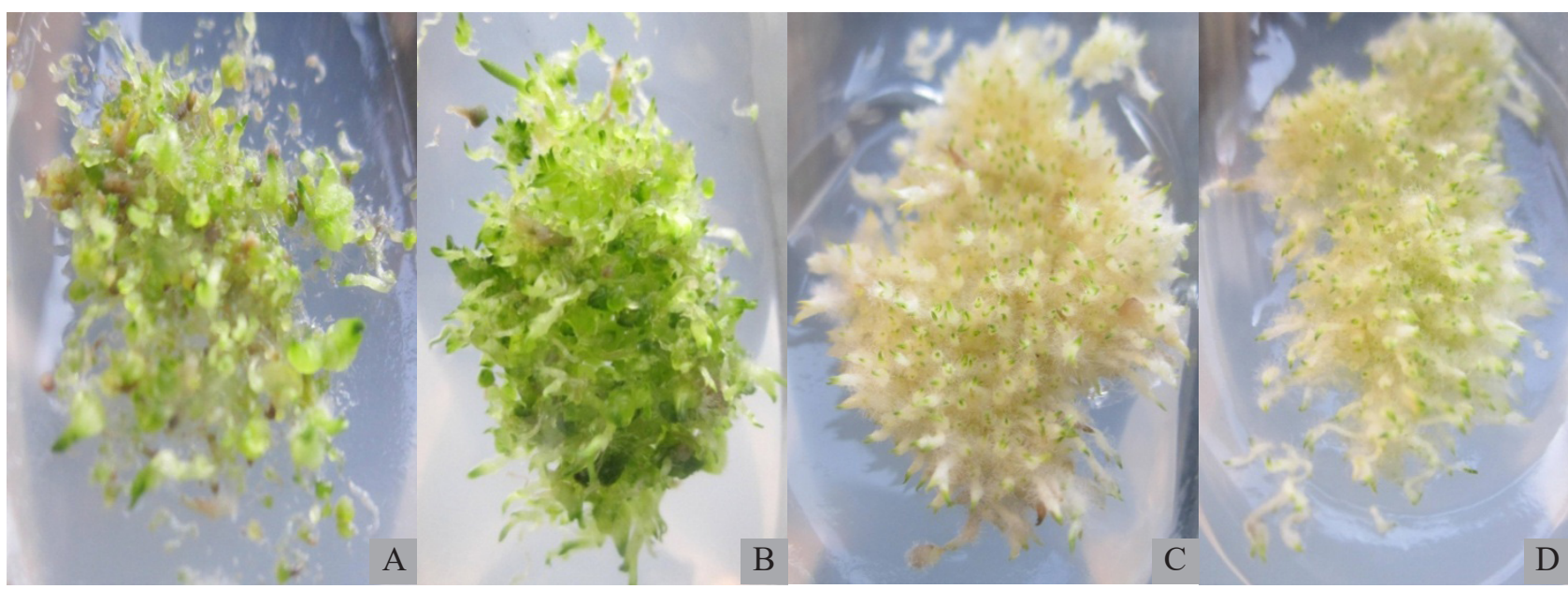

Figure 3: Development of protocorms from seeds on the full- and half-strength of MS medium (A and B) and on the half- and quarter-strength of $\mathrm{KnC}$-medium (C and D). 


\section{Multiplication of shoots on the different nutrient medium}

Protocorms were transferred on the half-strength of MS medium supplemented with $\mathrm{GA}_{3}(0.5,1.0,1.5$ and $2.0 \mathrm{mg} / \mathrm{l})$ with or without $0.5 \mathrm{mg} / \mathrm{L} \mathrm{NAA}$, and BAP $(0.5,1.0,1.5$ and $2.0 \mathrm{mg} / \mathrm{l})$ for their elongation and multiplication. The variation in the development of shoots from the inoculated explants has shown in Figure 4. Among the medium, $0.5 \mathrm{mg} / \mathrm{GA}_{3}$ supplemented half-strength of MS-medium was favoured for the development of more than 5 shoots per culture after 5 weeks (Figure 5A). Similarly, more than 4 shoots per culture were developed on the $\mathrm{GA}_{3}(0.5 \mathrm{mg} / \mathrm{l})$ plus NAA $(0.5 \mathrm{mg} / \mathrm{l})$ supplemented half-strength of MS medium after 4 weeks (Figure 5B). However, BAP (0.5 and 1.5 $\mathrm{mg} / \mathrm{l})$ supplemented half-strength of MS medium was favoured for development of more than 6 shoots in the $5^{\text {th }}$ week (Figure 5C).

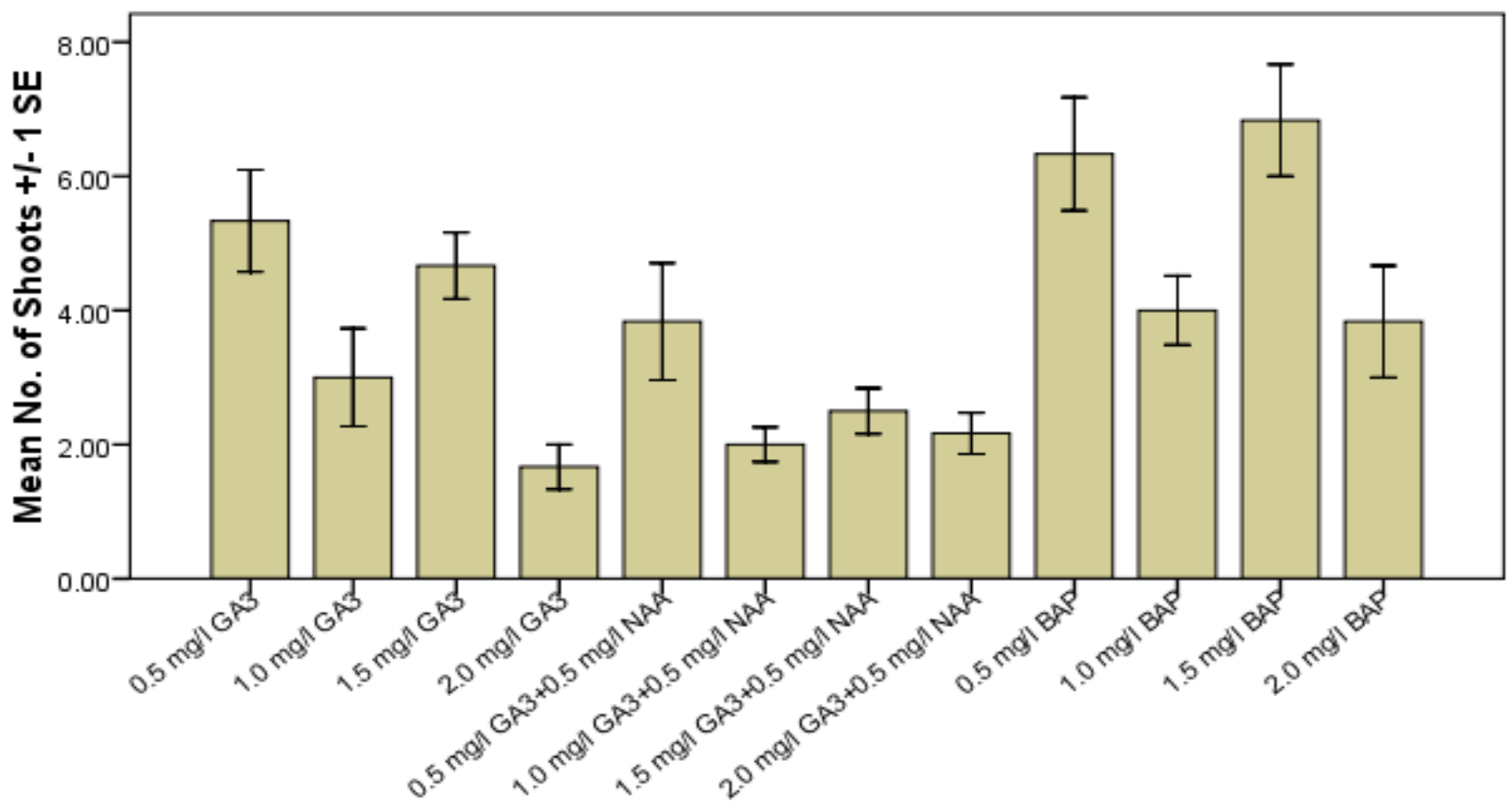

HormoneConcentration

Figure 4: Development of shoots from the protocorms on half-strength of MS medium with different hormones.

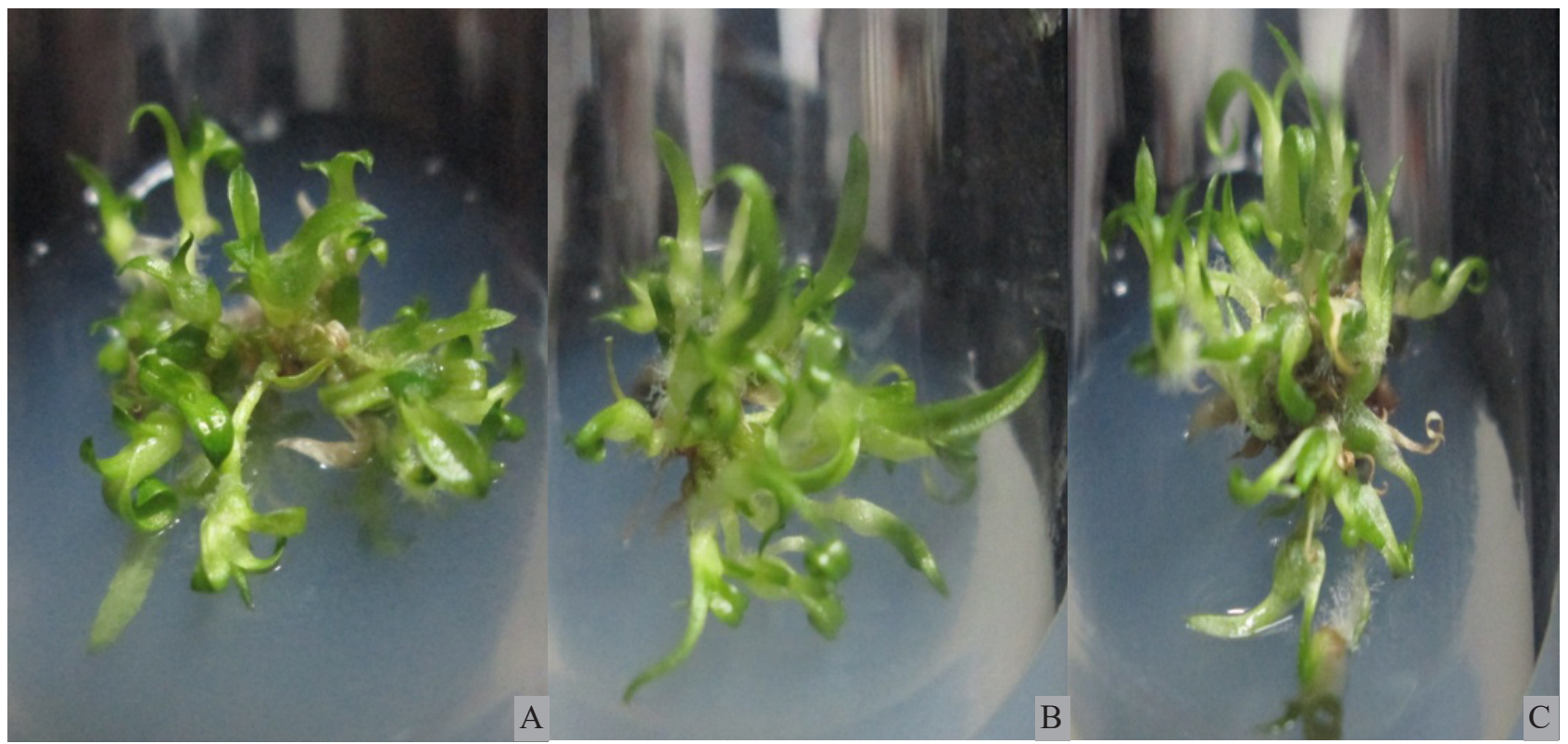

Figure 5: Development of shoots from protocorms on the half-strength MS medium with $0.5 \mathrm{mg} / 1 \mathrm{GA}$ (A), with $0.5 \mathrm{mg} / 1 \mathrm{GA}_{3}$ plus $0.5 \mathrm{mg} / 1 \mathrm{NAA}(\mathrm{B})$, and with $1.5 \mathrm{mg} / 1 \mathrm{BAP}(\mathrm{C})$. 


\section{Root formation on the different nutrient medium}

For the root formation, in vitro developed shoots were transferred on the NAA, IAA and IBA supplemented half-strength of MS medium. The higher number of roots were developed on the shoots in the IBA (0.5-
$1.0 \mathrm{mg} / \mathrm{l})$ and $0.5 \mathrm{mg} / \mathrm{lNAA}$ supplemented half-strength of MS medium (Figure 6). The high concentration of NAA $(1.0 \mathrm{mg} / \mathrm{l})$ was found to be in-effective for the formation of roots.

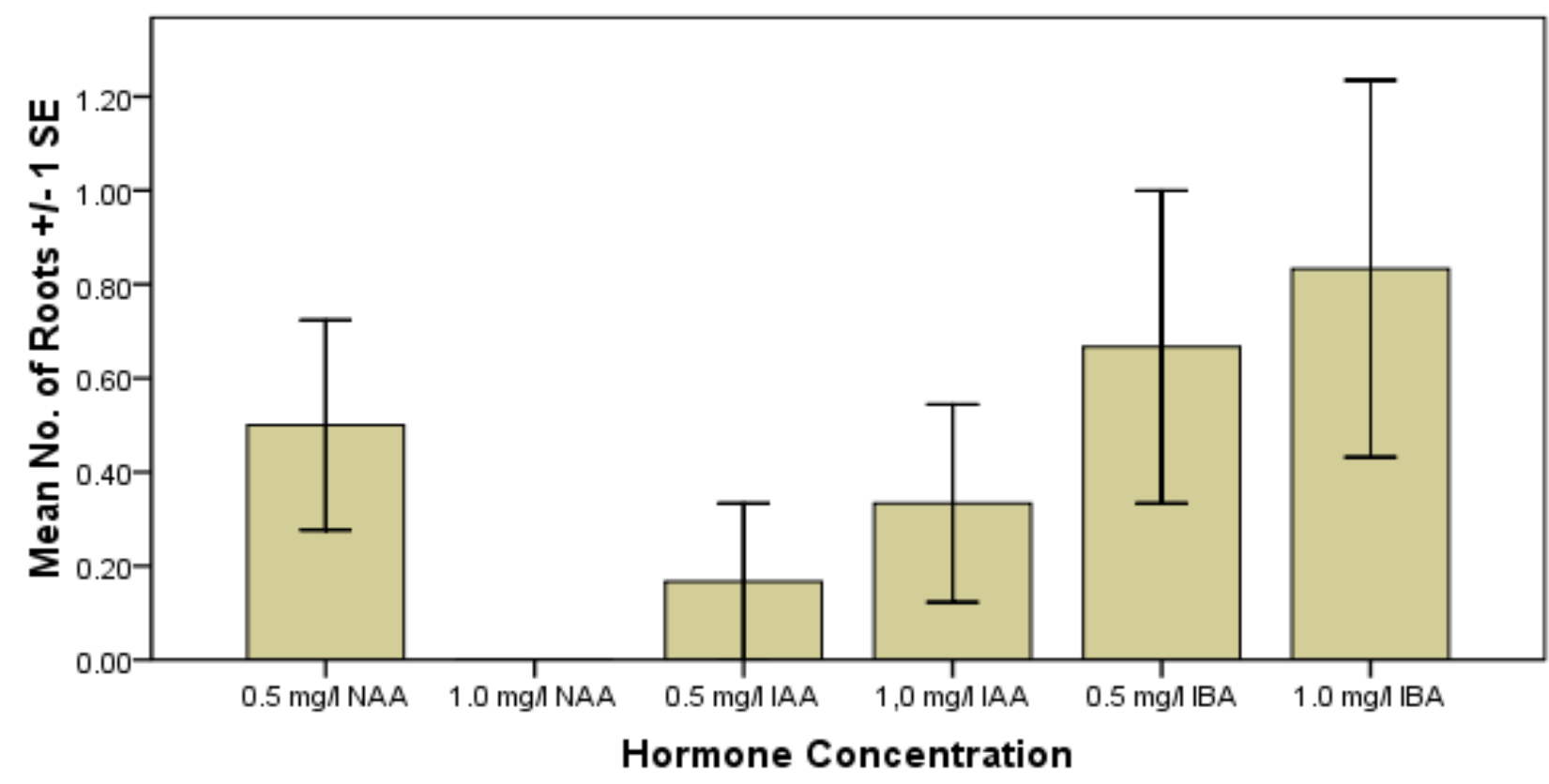

Figure 6: Formation of roots on the shoots on NAA, IAA and IBA supplemented half-strength of MS medium.

\section{Discussion}

Both MS and $\mathrm{KnC}$ medium showed varied response on non-symbiotic seed germination of $P$. articulata. The orchid seeds responded successively in half strength of $\mathrm{MS}$ and $\mathrm{KnC}$ medium but further development of shoots from germinating seeds was suppressed in different strengths of $\mathrm{KnC}$ medium. This is because of MS medium is highly enriched with macro and microelements with different vitamins whereas $\mathrm{KnC}$ medium contained a comparatively low amount of macro and microelements without vitamins (Pradhan \& Pant, 2009; Vejsadová, 2006). It was found that even though the time taken for germination and initiation of shoot formation was faster in $\mathrm{KnC}$ medium, it did not favour further development of shoots, as the shoots became achlorophyllous. The development of orchids requires a balanced supply of both organic and inorganic nutrients (Johnson et al., 2007). Though $\mathrm{KnC}$ medium was found to be best for the culture of many orchids, it did not favour Pholidota articulata. MS medium showed good response compared to $\mathrm{KnC}$ medium in seed germination and shoots formation which was found similar to the previous study in
Esmeralda clarkei (Paudel et al., 2012). This effect may be due to the presence of a high concentration of vitamins, amino acids and other regulatory compounds present in MS medium compared to $\mathrm{KnC}$ medium (Paudel \& Pant, 2013; Pradhan et al., 2013). Similar types of result have been reported to the previous findings of seed germination of orchids; Habenaria macroceratitis (Stewart \& Kane, 2006), Coelogyne mossiae (Sebastinraj et al., 2006), Coelogyne stricta (Parmar \& Pant, 2016), Cymbidium aloifolium (Pradhan et al., 2014; Pradhan et al., 2013).

$\mathrm{GA}_{3}$ treatment was found to be much effective in shoot multiplication (Giridhar \& Ravishankar, 2004; Maharjan et al., 2020). Half-strength MS medium supplemented with $0.2 \mathrm{mg} / 1 \mathrm{BAP}$ proved better for multiplication of protocorm and healthy shoot proliferation of Dendrobium (Nuraini et al., 2010), Phaius tancarvilleae (Pant \& Shrestha, 2011), multiple shoot production of Vanilla planifolia (Palama et al., 2010), multiple shoot productions in Dendrobium aqueum (Parthibhan et al., 2015), Esmeralda clarkei (Paudel \& Pant, 2012a, 
2012b), inducing multiple shoots in MS with additives of BA (Pant et al., 2019), as well as multiple shoot production in the combination of BAP and NAA (da Silva et al., 2015; da Silva \& Acharya, 2014). Rooting of a shoot in $0.5 \mathrm{mg} / \mathrm{l}$ NAA containing medium was the most appropriate as is supported by the previous works (Panwar et al., 2012; Pradhan et al., 2013; Zeng et al., 2012).IAA supplemented medium was found best for the initiation of the root in Dendrobium and Vanilla (Aktar et al., 2007; Geetha \& Shetty, 2000), similar to the present result.

\section{Conclusion}

Half-strength of MS medium was found to be the most appropriate for the non-symbiotic seeds germination and protocorms formation of Pholidota articulata. Half-strength of MS medium supplemented with 1.5 $\mathrm{mg} / \mathrm{l} \mathrm{BAP}$ was found to be the most effective condition for the multiplication of shoots from protocorms. Root development was found best on half-strength of MS medium supplemented with $1.0 \mathrm{mg} / 1 \mathrm{IBA}$. Hence, this protocol might be useful for non-symbiotic germination, mass propagation and conservation of Pholidota articulata.

\section{Acknowledgement}

Authors are gratefully acknowledge Mr. Mukesh Babu Chand for his kind help in laboratory work.

\section{Declaration of conflict of interest and ethical approval:}

Authors declared that there is no any type of competing interest regarding the current manuscript. R. D. Prasad did the experiment and wrote the draft, M. R. Paudel design the experiment, wrote and finalized the manuscript, S. Pradhan and B. Pant conceptualized, designed and supervised the experiment. All authors have read, reviewed and approved the manuscript before submitting to the journal.

The current article does not include any human or animal participation by the authors.

\section{References}

Aktar, S., Nasiruddin, K. M., \& Huq, H. (2007). In vitro root formation in Dendrobium orchid plantets with IBA. Journal of Agriculture \& Rural Development, 5, 48-51.
Chase, M. W., Cameron, K. M., Freudenstein, J. V., Pridgeon, A. M., Salazar, G., van den Berg, C., \& Schuiteman, A. (2015). An updated classification of Orchidaceae. Botanical Journal of the Linnean Society, 177, 151-174.

da Silva, J. A. T., \& Acharya, K. P. (2014). In Vitro Propagation of Nepalese Orchids: A Review. Journal of Horticultural Research, 22, 47-52.

da Silva, J. A. T., Cardoso, J. C., Dobránszki, J., \& Zeng, S. J. (2015). Dendrobium micropropagation: a review. Plant Cell Reports, 34, 671-704.

Geetha, S., \& Shetty, S. A. (2000). In vitro propagation of Vanilla planifolia, a tropical orchid. Current Science, 79, 886-889.

Giridhar, P., \& Ravishankar, G. A. (2004). Efficient micropropagation of Vanilla planifolia Andr. under influence of thidiazuron, zeatin and coconut milk. Indian Journal of Biotechnology, 3, 113-118.

Jalal, J. S., Tewari, L. M., \& Pangtey, Y. P. S. (2009). Pholidata articulata Lindl., An Orchid Used in Bone Jointing in Kumaun Region, Western Himalaya. Ethnobotanical Leaflets, 13, 10471050 .

Johnson, T. R., Stewart, S. L., Dutra, D., Kane, M. E., \& Richardson, L. (2007). Asymbiotic and symbiotic seed germination of Eulophia alta (Orchidaceae) - Preliminary evidence for the symbiotic culture advantage. Plant Cell, Tissue and Organ Culture, 90, 313-323.

Maharjan, S., Thakuri, L. S., Thapa, B. B., Pradhan, S., Pant, K. K., Joshi, G. P., \& Pant, B. (2020). In Vitro Propagation of the Endangered Orchid Dendrobium chryseum Rolfe from Protocorms Culture. Nepal Journal of Science and Technology, 19, 39-47.

Nuraini, A., Heriliya, W., Suminar, E., \& Marliana, E. (2010). Responses of protocorm like bodies hybrid Dendrobium orchid on various types and concentration of cytokinin and auxin on Murashige and Skoog (MS) medium. International Seminar on Horticulture to Support Food Security, 130-135.

Palama, T. L., Menard, P., Fock, I., Choi, Y. H., Bourdon, E., Govinden-Soulange, J., Bahut, M., Payet, B., Verpoorte, R., \& Kodja, H. (2010). Shoot 
differentiation from protocorm callus cultures of Vanilla planifolia (Orchidaceae): proteomic and metabolic responses at early stage. BMC Plant Biology, 10, 82.

Pant, B. (2013). Medicinal orchids and their uses: Tissue culture a potential alternative for conservation. African Journal of Plant Science, 7, 448-467.

Pant, B., Paudel, M. R., Chand, M. B., \& Wagner, S. H. (2016). A Treasure Trove of Orchids in Central Nepal. Central Department of Botany, Tribhuvan University, Kirtipur, Kathmandu, Nepal.

Pant, B., Pradhan, S., Paudel, M. R., Shah, S., Pandey, S., \& Joshi, P. R. (2019). Various culture techniques for the mass propagation of medicinal orchids from Nepal. Acta Horticulturae, 1262, 109-124.

Pant, B., Shah, S., Shrestha, R., Pandey, S., \& Joshi, P. R. (2017). An overview on orchid endophytes. In A. Varma, R. Prasad, \& N. Tuteja (Eds.), Mycorrhiza-Nutrient Uptake, Biocontrol, Ecorestoration (pp. 503-524). Springer.

Pant, B., \& Shrestha, S. (2011). In vitro mass propagtion of a ground orchid- Phaius tancarvilleae (L'Her.) Blume through shoot tip culture. Plant Tissue Culture and Biotechnology, 21, 181-188.

Panwar, D., Ram, K., Harish, N., \& Shekhawat, N. S. (2012). In vitro propagation of Eulophia nuda Lindl., an endangered orchid. Scientia Horticulturae, 139, 46-52.

Parmar, G., \& Pant, B. (2016). In vitro seed germination and seedling development of the orchid Coelogyne stricta (D. Don) Schltr. African Journal of Biotechnology, 15, 105-109.

Parthibhan, S., Rao, M. V., \& Kumar, T. S. (2015). In vitro regeneration from protocorms in Dendrobium aqueum Lindley - An imperiled orchid. Journal of Genetic Engineering and Biotechnology, 13, 227-233.

Paudel, M. R., \& Pant, B. (2012a). In vitro micropropagation of rare orchid (Esmeralda clarkei Rchb.f.) from shoot tip section. International Journal of Biology, Pharmacy and Allied Sciences, 1, 1587-1597.

Paudel, M. R., \& Pant, B. (2012b). In vitro plant regeneration of Esmeralda clarkei Rchb.f. via protocorm explant. African Journal of Biotechnology, 11, 11704-11708.
Paudel, M. R., \& Pant, B. (2013). A Reliable Protocol for Micropropagation of Esmeralda Clarkei Rchb.f. (Orchidaceae). Asia-Pacific Journal of Molecular Biology and Biotechnology, 21, 114120.

Paudel, M. R., Pradhan, S., \& Pant, B. (2012). In vitro seed germination and seedling development of Esmeralda clarkei Rchb.f. (Orchidaceae). Plant Tissue Culture and Biotechnology, 22, 107-111.

Pradhan, S., \& Pant, B. (2009). In vitro seed germination in Cymbidium elegans Lindl. and Dendrobium densiflorum Lindl. ex Wall. ( Orchidaceae ). Botanica Orientalis-Journal of Plant Science, 6 , 100-102.

Pradhan, S., Paudel, Y. P., \& Pant, B. (2013). Efficient regeneration of plants from shoot tip explants of Dendrobium densiflorum Lindl., a medicinal orchid. African Journal of Biotechnology, 12, 1378-1383.

Pradhan, S., Regmi, T., Parmar, G., \& Pant, B. (2013). Effect of Different Media on in vitro Seed Germination and Seedling Development of Cymbidium aloifolium (L.) Sw. Nepal Journal of Science and Technology, 14, 51-56.

Pradhan, S., Tiruwa, B., Subedee, B. R., \& Pant, B. (2014). In vitro germination and propagation of a threatened medicinal orchid, Cymbidium aloifolium (L.) Sw. through artificial seed. Asian Pacific Journal of Tropical Biomedicine, 4, 971976.

Rajbhandari, K. R. (2014). Orchids of Nepal: Status, threat and conservation. Proceedings of National Workshop on NTFP/MAPs Sector Action Plant Development: Orchid, 1-40.

Sebastinraj, J., Britto, J. S., Robinson, P. J., Kumar, V. D., $\&$ Kumar, S. S. (2006). In vitro seed germination and plantlet regeneration of Coelogyne mossiae Rolfe. Journal of Biological Research, 5, 79-84.

Sharma, C., Irshad, S., Khatoon, S., \& Arya, K. R. (2017). Pharmacognostical evaluation of Indian folk-traditional plants Coelogyne cristata and Pholidota articulata used for healing fractures. Indian Journal of Experimental Biology, 55, 622-627.

Stewart, S. L., \& Kane, M. E. (2006). Symbiotic seed germination of Habenaria macroceratitis 
(Orchidaceae), a rare Florida terrestrial orchid. Plant Cell, Tissue and Organ Culture, 86, 147158.

Subedi, A., Kunwar, B., Choi, Y., Dai, Y., van Andel, T., Chaudhary, R. P., de Boer, H. J., \& Gravendeel, B. (2013). Collection and trade of wild-harvested orchids in Nepal. Journal of Ethnobiology and Ethnomedicine, 9, 64.

Vejsadová, H. (2006). Factors affecting seed germination and seedling growth of terrestrial orchids cultured in vitro. Acta Biologica Cracoviensia Series Botanica, 48, 109-113.

Zeng, S. J., Wu, K. L., da Silva, J. A. T., Zhang, J. X., Chen, Z. L., Xia, N. H., \& Duan, J. (2012). Asymbiotic seed germination, seedling development and reintroduction of Paphiopedilum wardii Sumerh., an endangered terrestrial orchid. Scientia Horticulturae, 138, 198-209. 